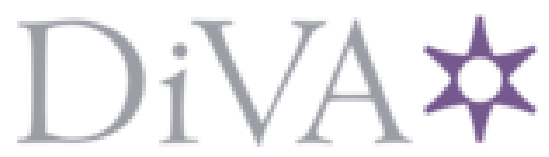

http://www.diva-portal.org

\title{
Preprint
}

This is the submitted version of a paper published in Archives of Toxicology.

Citation for the original published paper (version of record):

Gustafsson, S., Wallenius, A., Zackrisson, H., Popova, D., Plym Forshell, L. et al. (2013)

Effects of cannabinoids and related fatty acids upon the viability of P19 embryonal carcinoma cells.

Archives of Toxicology, 87(11): 1939-1951

http://dx.doi.org/10.1007/s00204-013-1051-3

Access to the published version may require subscription.

N.B. When citing this work, cite the original published paper.

Permanent link to this version:

http://urn.kb.se/resolve?urn=urn:nbn:se:umu:diva-51550 


\title{
Manuscript
}

\section{Effects of cannabinoids and related fatty acids upon the viability of P19 embryonal carcinoma cells}

\author{
Sofia B. Gustafsson · Anders Wallenius · Hanna Zackrisson • Dina Popova • Linus Plym \\ Forshell $\cdot$ Stig O. P. Jacobsson
}

Submitted for publication

\begin{abstract}
Compounds acting on the cannabinoid (CB) receptors are involved in the control of cell fate, and there is an emerging consensus that $\mathrm{CBs}$ have anticancer effects. However, the CB-mediated effects are contradictory since some studies suggest stimulatory effects on cancer cell proliferation, and CBs have been shown to stimulate both proliferation and differentiation of other mitotic cells such as stem and progenitor cells. In this study, the concentration-dependent effects of synthetic and endogenous CBs on the viability of mouse P19 embryonal carcinoma (EC) cells have been examined by using fluorescence assays of cell membrane integrity, cell proliferation, oxidative stress, and detection of apoptosis and necrosis. All compounds examined produced a concentrationdependent decrease in cell viability in the micromolar range, with the potent $\mathrm{CB}$ receptor agonist HU 210 and the enantiomer HU 211(with no $\mathrm{CB}$ receptor activity) being the most potent compounds examined with apparent $\mathrm{IC}_{50}$ values of 1 $\mu \mathrm{M}$ and $0.6 \mu \mathrm{M}$, respectively. The endogenous $\mathrm{CB}$ anandamide showed similar potency and efficacy as structurally related polyunsaturated fatty acids with no reported activity at the $\mathrm{CB}$ receptors. The rapid (within hours) decrease in cell viability induced by the examined CBs suggests cytocidal rather than antiproliferative effects, and is dependent on the plating cell population density with the highest toxicity around 100 cells $/ \mathrm{mm}^{2}$. The CB-induced cytotoxicity, that appears to involve $\mathrm{CB}$ receptors and the sphingomyelin-ceramide pathway, is a mixture of both apoptosis and necrosis that can be blocked by the antioxidants $\alpha$-tocopherol and $N$ acetylcysteine. In conclusion, both synthetic and endogenous $\mathrm{CBs}$, produce seemingly unspecific cytotoxic effects in the P19 EC cells.
\end{abstract}

\footnotetext{
S.B. Gustafsson · A. Wallenius · H. Zackrisson · D. Popova · L. Plym Forshell· S.O.P. Jacobsson $(\bowtie)$

Department of Pharmacology and Clinical Neuroscience, Umeå

University, SE-901 87 Umeå, Sweden

e-mail: stig.jacobsson@pharm.umu.se

Tel: +46-90-7852713 Fax: +46-90-7852752
}

Key words cannabinoids - polyunsaturated fatty acids - embryonal carcinoma cells $\cdot$ cytotoxicity oxidative stress

\section{Introduction}

Research on the cannabinoid (CB) system in various physiological functions and pathological conditions gained increased significance after the discovery of the two G-protein-coupled $\mathrm{CB}$ receptors $\mathrm{CB}_{1}$ and $\mathrm{CB}_{2}$ (Matsuda et al. 1990; Munro et al. 1993), and their endogenous ligands in the beginning of the 1990's (Devane et al. 1992b; Mechoulam et al. 1995; Sugiura et al. 1995). CBs have shown therapeutic potential in a wide range of pathological conditions, including chronic pain, inflammation, obesity, drug addiction, neurotoxicity, spasticity, anxiety, depression, and Parkinson's disease (for a review, see Pacher et al. 2006).

It is clear that the CB system plays an important modulatory role in controlling the cell fate in many tissues and organs, but the results from various studies are contradictory. One of the most intriguing areas of current research in the therapeutic potential of CBs is cancer. Various plant-derived, synthetic and endogenous ligands at the $\mathrm{CB}$ receptors have been shown to inhibit cell proliferation and promote differentiation and apoptosis, and several studies have demonstrated antitumoral actions of $\mathrm{CB}$ receptor agonists in both in vitro and in vivo models of cancer (for reviews, see Flygare and Sander 2008; Guzman 2003), but there are also in vitro studies demonstrating stimulatory effects of CBs on cancer cell proliferation (Hart et al. 2004; Takeda et al. 2008).

Given the effects of various CBs on tumor cells, another area where the $\mathrm{CB}$ system has gained increased attention is the process of the embryonic development (Fride 2008; Taylor et al. 2007), and studies have been undertaken in order to investigate the effects of $\mathrm{CBs}$ on stem and progenitor cells (Aguado et al. 2005; Jiang et al. 2007; Jiang et al. 2005; Molina-Holgado et al. 2007; Rubio-Araiz et al. 2008; Rueda et al. 2002). Evidence suggests that both synthetic CBs (e.g. HU 210) and endogenous 
CBs (e.g. anandamide; AEA) promote neuronal progenitor cell proliferation, but inhibit differentiation (Jiang et al. 2005; Rueda et al. 2002). In murine embryonic stem cell-derived embryoid bodies, the expression of $\mathrm{CB}_{1}$ and $\mathrm{CB}_{2}$ receptors are induced during hematopoetic differentiation and antagonists at $\mathrm{CB}_{1}$ and $\mathrm{CB}_{2}$ receptors (AM251 and AM630, respectively) induced embryonal stem cell death, whereas $\Delta^{9}$-tetrahydrocannabinol $\left(\Delta^{9}\right.$-THC), the principal psychoactive ingredient of hemp plant Cannabis sativa, enhanced the hematopoetic differentiation (Jiang et al. 2007).

The discrepancies between different studies may depend on 1) contrasting responsiveness between different cells, tissues or species, 2) differences in the activity of the diverse $\mathrm{CB}$ receptor ligands, and not least 3) differences in the experimental conditions used in the studies (e.g. drug concentrations and exposure time). Many studies are aimed at exploring the effect of single ligand at $\mathrm{CB}$ receptor in a particular cell type, by using a single method to validate toxicity.

In this study we have addressed some of these issues. We are investigating the role of the $\mathrm{CB}$ system in P19 embryonal carcinoma (EC) cells, that have native expression of $\mathrm{CB}$ receptors (Svensson et al. 2006), and due to the unique properties of this class of cells that have been characterized as the "stem cells" of tumors, the P19 EC cell line is a good in vitro cell system for studying mechanisms of both anticancer effects and developmental toxicity. However, a thorough characterization of the effects of various CB receptor ligands on P19 EC cell proliferation and viability is lacking. Therefore, we have investigated the concentrationdependent effects of synthetic (HU 210, WIN 55,212-2, meth-AEA), and endogenous (AEA, $\mathrm{N}$ arachidonoyl glycine; NAGly), CBs, but also related compounds with no reported activity at the $\mathrm{CB}$ receptors, such as the plant-derived $\mathrm{CB}$ cannabidiol (CBD), the synthetic enantiomer of HU 210, HU 211 , and two polyunsaturated fatty acids structurally related to AEA (arachidonic acid; AA, eicosapentaenoic acid; EPA), on the viability of P19 EC cells. Several different methods have been used to assess cell toxicity, including fluorescence assays of cell membrane integrity, cell proliferation, oxidative stress, and analysis of cell cycle profile and detection of apoptosis and necrosis. Secondly, a pharmacological approach have been used in order to determine whether effects are $\mathrm{CB}$ receptormediated or not, and to elucidate any differences in the mechanisms behind the cellular effects of the synthetic analogue of $\Delta^{9}$-THC, HU 210 , and the endogenous CB AEA. For that purpose, a wide range of compounds have been examined, targeting different cellular pathways suggested to be involved in the antitumoral action of CBs.

\section{Materials and methods}

Chemicals

Calcein-AM, CyQUANT ${ }^{\circledR}$ Cell Proliferation Assay kit, YO-PRO ${ }^{\circledR}-1$ iodide, propidium iodide, $\mathrm{H}_{2}$ DCFDA (2',7'-dichlorodihydrofluorescein diacetate), MEM- $\alpha$ medium (with deoxyribonucleosides and ribonucleosides), MEM non-essential amino acids (NEAA), penicillin-streptomycin (PEST), fetal bovine serum (FBS), and trypsin-EDTA were purchased from Invitrogen Life Technologies (Uppsala, Sweden). AM251 (N-(Piperidin-1-yl)-5-(4-iodophenyl)-1-(2,4dichlorophenyl)-4-methyl-1H-pyrazole-3-

carboxamide), AM630 (6-Iodo-2-methyl-1-[2-(4morpholinyl)ethyl]-1H-indol-3-yl](4-methoxyphenyl) methanone), HU-210 ((6aR)-trans-3-(1,1dimethylheptyl)-6a,7,10,10a-tetrahydro-1-hydroxy6,6-dimethyl-6H-dibenzo[b,d]pyran-9-methanol), arachidonoylglycine $\quad(N-(1-0 x 0-5 Z, 8 Z, 11 Z, 14 Z-$ eicosatetraenyl)glycine; NAGly), L-NAME hydrochloride (NG-nitro-L-arginine methyl ester hydrochloride), $R-(+)$-methanandamide (methAEA), SB366791 (4'-chloro-3-methoxycinnamanilide), WIN 55,212-2 ((R)-(+)-[2,3-Dihydro-5-methyl-3-(4morpholinylmethyl)pyrrolo[1,2,3-de)-1,4-benzoxazin6-yl]-1-napthalenylmethanone, were purchased from Tocris Cookson (Bristol, UK). Anandamide ( $N-(2-$ hydroxyethyl)-5Z,8Z,11Z,14Z-eicosatetraenamide; AEA), GW 9662 (2-chloro-5-nitrobenzanilide), and HU 211 (3-(1,1-dimethylheptyl)-6aS, 7, 10,10aStetrahydro-1-hydroxy-6,6-dimethyl-6H- dibenzo[b,d]pyran-9-methanol; dexanabinol) were purchased from Cayman Chemical Co. (Ann Arbor, MI, USA). Nacetyl-L-cysteine (NAC), arachidonic acid (cis,cis,cis,cis-5,8,11,14-eicosatetraenoic acid; AA), capsazepine $\quad(N$-[2-(4-chlorophenyl)ethyl]-1,3,4,5tetrahydro-7,8-dihydroxy-2H-2-benzazepine-2-carbothioamide), EPA (cis-5,8,11,14,17-eicosapentaenoic acid), fumonisin $\mathrm{B}_{1}$, methyl cyclodextrin (MCD), poly-D-lysine, $\alpha$-tocopherol (vitamin E), Sigmacoat ${ }^{\circledR}$, pertussis toxin (PTX) and insulin were purchased from Sigma Chemical Co. (St Louis, MO, USA). Culture flasks (T-75), 15 and $50 \mathrm{ml}$ tubes, 5 and $10 \mathrm{ml}$ serological pipettes were from Sarstedt, Germany, whereas $1.5 \mathrm{ml}$ Eppendorf tubes were from Eppendorf, Germany. Six-well and 96-well clearwalled Nunclon Delta surface plates were from Nunc A/S, Denmark. 24-well clear-walled plates and 96well black-walled plates were from Corning Inc., USA.

\section{Assays of cell viability, apoptosis, proliferation, and} oxidative stress

P19 cells (passage 9-50) from European Collection of Cell Cultures (Porton Down, U.K.) were grown in 75 $\mathrm{ml}$ cell culture flasks in MEM- $\alpha$ medium supplemented with $10 \%$ FBS, $1 \%$ PEST and $1 \%$ 
NEAA. Cells were kept at $37^{\circ} \mathrm{C}$ in an incubator with humidified atmosphere and supplied with $5 \% \mathrm{CO}_{2}$. The medium was changed every second day and the cells were passaged to new $75 \mathrm{ml}$ flasks every fourth day.

On the day before the experiments, the P19 cells cells were trypsinized and plated in black-walled 96-well plates at a population density of $3000-30000$ cells/well in $180 \mu \mathrm{l}$ of MEM- $\alpha$ medium with $1 \%$ FBS, $1 \%$ PEST , $1 \%$ NEAA. The experiments were initiated by adding $20 \mu \mathrm{l}$ of the test compounds (cannabinoids or fatty acids) in triplicates dissolved in culture medium, to a final volume of $200 \mu \mathrm{l}$. For the experiments with enzyme inhibitors, receptor antagonists and antioxidants, these compounds were added in a volume of $20 \mu \mathrm{l}$ one to two hours prior to the addition of cannabinoids (except pertussis toxin that was preincubated for 16 hours). The final solvent (DMSO and/or EtOH) concentration was kept constant at $0.5 \%$ in all assays, except for untreated control wells. All experimental treatments were carried out in triplicates in each experiment to compensate for biological and experimental variation. The exposure time at $37^{\circ} \mathrm{C}$ in an incubator with humidified atmosphere and supplied with $5 \% \mathrm{CO}_{2}$, ranged from 2 to 96 hours followed by analysis of the cell viability, apoptosis/necrosis, proliferation and oxidative stress. When the cells were exposed to the test compounds for 4 days, the culture media was changed every second day.

Cell viability: Cell viability was assessed by measuring the transport of calcein-AM through the cellular membrane of live cells. Intracellular esterases of live cells induce a fluorescent calcein, whereas dead cells lack esterase activity. Briefly, the exposure to test compounds was terminated by washing the cells with PBS ( $\mathrm{pH} 7.2$ ), followed by the addition of 1 $\mu \mathrm{M}$ calcein-AM in a final volume of $200 \mu \mathrm{l}$. After 60 min of incubation at room temperature in the dark, the sample fluorescence was measured (excitation/ emission: $485 / 520 \mathrm{~nm}$ ) in a FLUOstar Galaxy microplate reader (BMG Labtechnologies $\mathrm{GmbH}$, Offenburg, Germany). In control wells, 2\% Triton X100 was added to assess the amount of fluorescence in cultures with maximal cell death.

Apoptosis, necrosis and oxidative stress: Measurement of apoptosis, necrosis, and oxidative stress were preformed in a fluorescence microplate assay according to Plantin-Carrenard et al. (2003). Cells (plated at a population density of 20000 cells/well in MEM medium w/o phenol red) were allowed to settle for 18 hours, followed by four hours exposure to the test compounds. The plates were placed on ice, and incubated with $1 \mu \mathrm{M}$ YO-PRO-1 or $10 \mu \mathrm{g} / \mathrm{ml}$ propidium iodide (PI) for additional 30 minutes in a total volume of $110 \mu$ l. The YO-PRO-1 dye is transported into cells undergoing apoptosis, but excluded from viable cells. PI is cell membrane impermeant and is used to detect necrotic cells as it by binds to nucleic acids and generates an enhanced fluorescence. The fluorescence from cell undergoing apoptosis and/or necrosis was measured in the FLUOstar Galaxy microplate reader (excitation/emission: 485/510 $\mathrm{nm}$ for YO-PRO-1 and $544 / 620 \mathrm{~nm}$ for PI). Assessment of oxidative stress was measured by incubating the cells with $5 \mu \mathrm{M}$ $\mathrm{H}_{2}$ DCFDA in Hank's buffered salt solution (HBSS) for 30 minutes at $37^{\circ} \mathrm{C}$, and the basal fluorescence level was measured at excitation/emission: 485/520 $\mathrm{nm}$, using the FLUOstar Galaxy microplate reader. The test compounds were added and the fluorescence was measured every hour up to 3 hours.

Cell proliferation: Cell proliferation was analyzed using the CyQUANT cell proliferation assay or the $\left[{ }^{3} \mathrm{H}\right]$-thymidine incorporation assay. The CyQUANT assay quantifies the total amount of nucleic acid in the wells, and was performed according the manufacturer's instructions. Briefly, the exposure to test compounds was terminated by gently inverting the microplate and blotting it onto a paper towel, followed by freezing $\left(-80^{\circ} \mathrm{C}\right)$ until analysis. The fluorescent reagents were added and after 3 minutes incubation at room temperature in the dark, the samples were measured (excitation/emission: 485/520 $\mathrm{nm}$ ) in the FLUOstar Galaxy microplate reader. The $\left[{ }^{3} \mathrm{H}\right]$-thymidine incorporation assay was performed in 96-well microplates with 8000 cells/well that were incubated for 24 hours at $37^{\circ} \mathrm{C}$, followed by the addition of the test compounds. After 42 hours, 0.04 $\mu \mathrm{Ci}$ methyl- $\left[{ }^{3} \mathrm{H}\right]$-thymidine was added to each well and the cells were incubated for an additional 18 hours. The cells were harvested by vacuum filtration through a FilterMAT filter (Skatron Instruments, Sterling, USA) using a Micro Cell Harvester (Skatron Instruments) and the samples were dissolved in Ultima Gold scintillation fluid and the tritium content analyzed by liquid scintillation spectroscopy with quench correction in a WinSpectralTM liquid scintillation counter (PerkinTM Elmer, Wellesley, USA).

Cell cycle analysis: Cultured P19 cells were trypsinized and pelleted by centrifugation, $400 \mathrm{~g}$ for 5 minutes, together with its cell culture supernatant. After one wash in ice cold PBS, cell pellets were redissolved in $500 \mu \mathrm{l}$ Vindelöv reagent $(10 \mathrm{mM}$ Tris, $50 \mu \mathrm{g} / \mathrm{ml} \mathrm{PI}, 10 \mathrm{mM} \mathrm{NaCl}, 0.1 \%$ Igepal, and $700 \mathrm{U} / \mathrm{L}$ RNase). The PI-stained cells were kept in the dark at $4^{\circ} \mathrm{C}$ for 30 to 60 minutes and were analyzed on a Guava flow cytometer (Millipore, Billerica, USA) using the Red channel in linear scale. Collected data was analyzed using the Guava InCyte software (Millipore, Billerica, USA). 


\section{Data and statistical analyses}

Data are presented as either untransformed fluorescence units or percentages of untreated controls. The $\mathrm{IC}_{50}$ values from the concentrationeffect experiments were calculated by non-linear regression (sigmoidal dose-response curves) using GraphPad Prism 5 computer programme software for Windows (GraphPad Software Inc., San Diego, CA, U.S.A.). The computer-generated curves from the built-in equation "Bell-shaped", were constrained by setting the bottom plateau (maximal toxicity) to be zero or greater, from which the apparent concentrations that give half-maximal stimulatory $\left(\mathrm{EC}_{50[\mathrm{stim}]}\right)$ and inhibitory $\left(\mathrm{IC}_{50}\right)$ effects were obtained. Statistically significant differences (paired $t$ test, analysis of variance [ANOVA], and post-hoc tests) were undertaken using the GraphPad Prism software. See details of each statistical analysis used in the legends to figures. All analyses were repeated at least three times.
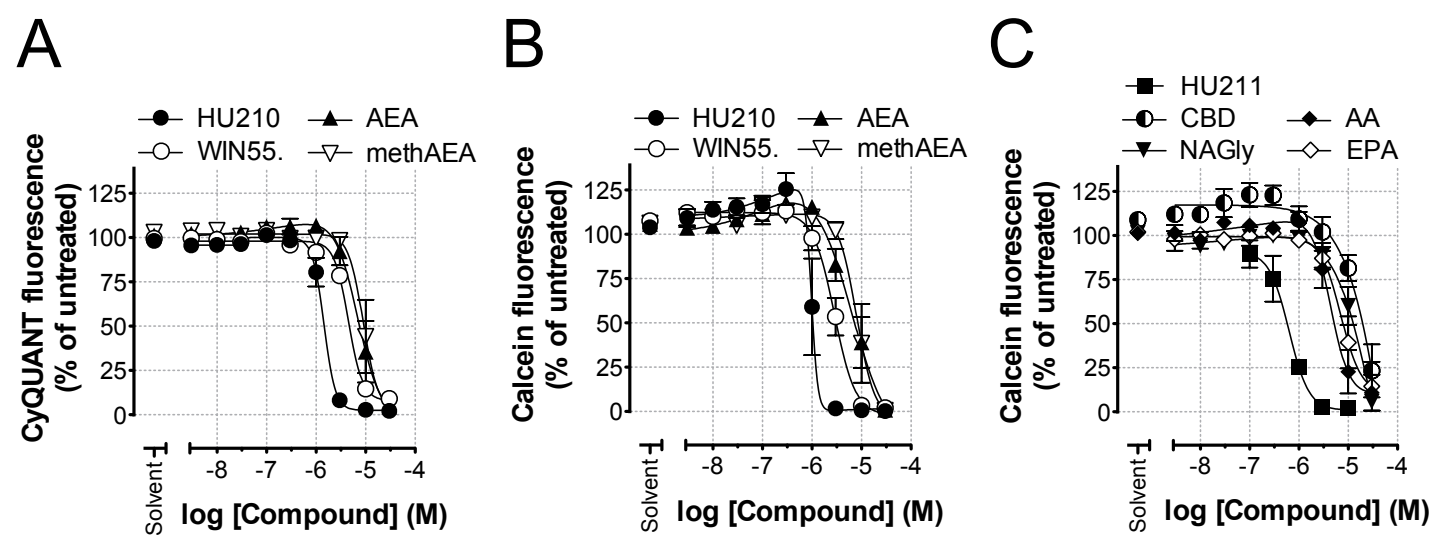

Fig. 1 Effects of various CB receptor agonists and related compounds on mouse P19 EC cell viability. After four days of exposure to indicated concentration of test compound in MEM- $\alpha$ medium with $1 \%$ FBS, the cells were analyzed for (a) nucleic acid content using the CyQUANT proliferation assay, and $(\mathbf{b}, \mathbf{c})$ intracellular accumulation of calcein-AM. "Solvent" indicate control cells treated with $0.5 \%$ DMSO or ethanol, used as carriers for the test compounds. Data (means \pm SEM of five to seven independent experiments) are plotted as percentage change in fluorescence units from untreated control cultures.

\section{Results}

Cannabinoids and fatty acids produce concentrationdependent cytotoxicity in P19 EC cells

The effects of the synthetic cannabinoids HU 210, WIN 55,212-2 and the metabolically stable AEA analogue meth-AEA, and the endogenous cannabinoid AEA on P19 EC cell proliferation were examined by using the CyQUANT proliferation assay, and the concentration-response curves are shown in Fig. 1a. These cannabinoids have agonist activity at the $\mathrm{CB}$ receptors, and after four days of exposure all compounds showed antiproliferative effects. HU 210 was the most potent compound examined, with an apparent $\mathrm{IC}_{50}$ value of $1.4 \mu \mathrm{M}$ (the $\mathrm{IC}_{50}$ value for WIN 55,212-2 was $4.5 \mu \mathrm{M}$, meth-AEA $7.0 \mu \mathrm{M}$, and AEA 9.0 $\mu \mathrm{M}$ ). Almost identical results were obtained when the P19 EC cell viability after four days of exposure were examined by measuring intracellular accumulation of calcein-AM (Fig. 1b), with $\mathrm{IC}_{50}$ values of $0.98 \mu \mathrm{M}$ for $\mathrm{HU} 210,2.8 \mu \mathrm{M}$ for WIN 55,212-2, $7.9 \mu \mathrm{M}$ for meth-AEA and $5.7 \mu \mathrm{M}$ for AEA. Even compounds with no or very low agonistic activity at the $\mathrm{CB}$ receptors decreased the cell viability after four days of exposure (Fig 1c). HU 211, the enantiomer of HU 210, lacking activity at $\mathrm{CB}$ receptors but acting as a glutamate NMDA receptor antagonist (Feigenbaum et al. 1989), also showed a potent cytotoxic effect on P19 EC cell viability with an apparent $\mathrm{IC}_{50}$ of $0.63 \mu \mathrm{M}$ using the calcein-AM assay. CBD, a non-psychoactive constituent of the plant Cannabis sativa with low affinity for the $\mathrm{CB}_{1}$ receptor but behaving as an inverse agonist at the $\mathrm{CB}_{2}$ receptor (Thomas et al. 2007), decreased the P19 cell viability with apparent $\mathrm{IC}_{50}$ value of $14 \mu \mathrm{M}$ (Fig. 1c), and the endogenous AEA-like compound NAGly that lacks affinity for the CB and TRPV1 receptors, had an apparent $\mathrm{IC}_{50}$ value of $29 \mu \mathrm{M}$. Even the PUFAs AA and EPA, with no reported $\mathrm{CB}$ receptor activity, showed almost identical concentration-effect curves (apparent $\mathrm{IC}_{50}$ value of $4.4 \mu \mathrm{M}$ and $7.1 \mu \mathrm{M}$, respectively), as AEA and meth-AEA (that are $\mathrm{CB}$ receptor agonists but also contain an arachidonoyl moiety).

Using the calcein-AM assay, a small concentrationdependent increase in fluorescence in cells treated with nanomolar concentrations of HU 210, AEA, meth-AEA, and CBD could be seen $(\sim 25 \%$ above the untreated controls). This could be a proliferative effect in this cell line, which prompted us to expose the cells to $10 \mathrm{nM}$ and $300 \mathrm{nM}$ of HU 210 or AEA followed by analysis of $\left[{ }^{3} \mathrm{H}\right]$-thymidine incorporation (after two days of exposure) in addition to calcein and CyQUANT fluorescence. 
A

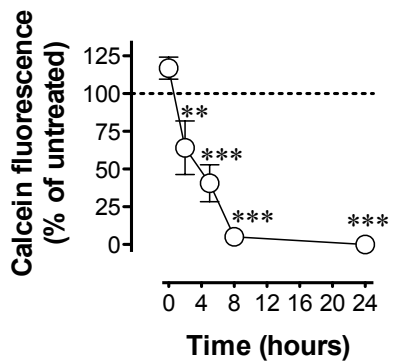

B

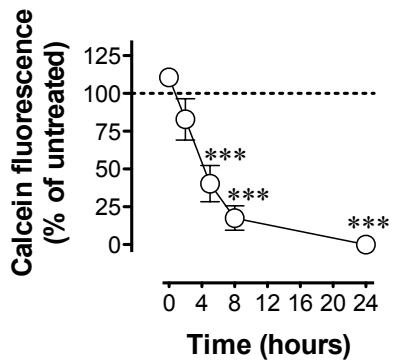

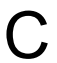

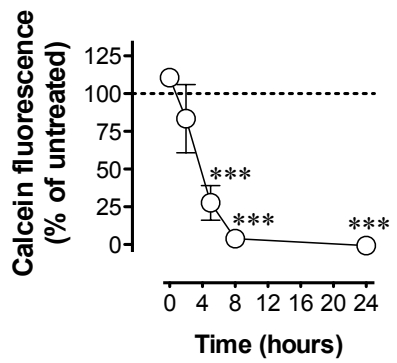

Fig. 2 Time-dependent cytotoxicity of (a) $10 \mu \mathrm{M}$ HU 210, (b) $30 \mu \mathrm{M}$ AEA, and (c) $30 \mu \mathrm{M}$ meth-AEA in P19 EC cells, as measured by the intracellular accumulation of calcein-AM. Data are means \pm SEM of four separate experiments. Statistically significant differences (one-way ANOVA with post-hoc Dunnett's multiple comparison test) from time 0 are indicated as $* * \mathrm{P}<0.01$ and $* * * \mathrm{P}<0.001$.

$\left[{ }^{3} \mathrm{H}\right]$-thymidine incorporation into cellular nucleic acid is dependent on the cell cycle status, and is a more sensitive measure of the proliferation rate than intracellular calcein-AM fluorescence or the CyQUANT proliferation kit. However, no statistically significant effects of HU 210 or AEA on CyQUANT fluorescence or $\left[{ }^{3} \mathrm{H}\right]$-thymidine incorporation in P19 cells were obtained (data not shown). Moreover, the FACS analysis showed that there was no difference in cell cycle profile between untreated controls, vehicle controls, or cell treated with $0.1 \mu \mathrm{M}$ HU 210 (data not shown). At $10 \mu \mathrm{M}$ of $\mathrm{HU} 210$ there were few cells to harvest and the majority were dead (sub-G1 in the FACS analysis).

In a previous study, we found that the CBs produce cytocidal, rather than antiproliferative effects in human colorectal carcinoma cells (Gustafsson et al. 2009), and this can also be shown in the mouse P19 EC cells. High concentrations of HU 210, AEA and meth-AEA induced a significant cytotoxicity within a couple of hours of incubation (Fig. 2), as measured by a decrease in fluorescence of intracellular calcein. After 8 hours of incubation with HU 210 or AEA, the calcein fluorescences were $4-17 \%$ of untreated controls and after 24 hours no fluorescence could be measured. We also found that the cytotoxicity was dependent on the cell population density in the culture wells (Online Resources 1). At a plating density of $\sim 60$ cells $/ \mathrm{mm}^{2}$, a five hour exposure to $1 \mu \mathrm{M} \mathrm{HU} 210$ decreased the calcein fluorescence by $44 \pm 13 \%$ and $10 \mu \mathrm{M}$ AEA decreased the fluorescence by $59 \pm 5 \%$ compared to untreated controls. However, at a plating density $>1500$ cells $/ \mathrm{mm}^{2}$ the same concentrations of the CBs produced no significant effect on the cell viability. This correlation between plating density and CB-induced cytotoxicity was also observed when the cells were challenged with $3 \mu \mathrm{M}$ HU 210 and $30 \mu \mathrm{M}$ AEA.
Involvement of oxidative stress in the CB-induced cell death that appears to be a mixture of both apoptosis and necrosis

CBs, e.g. the plant-derived $\Delta^{9}$-THC and the endogenous AEA, have been suggested to be cytoand neuroprotective by acting as antioxidants. On the other hand, recent studies propose that activation of $\mathrm{CB}_{1}$ receptors may induce oxidative stress (Rajesh et al. 2010), and it is well known that even low levels of reactive oxygen species (ROS) may induce apopototic cell death whereas high levels cause necrotic cell death (Lennon et al. 1991). In this study, we examined if $\mathrm{CBs}$ and related compounds induce oxidative stress and whether this contributes to the cytotoxic effects. Compound-induced increase in ROS was measured by monitoring changes in the fluorescence of the free radical sensor $\mathrm{H}_{2}$ DCFDA (Fig. 3), and parallel cultures were monitored for changes in the fluorescence of propidium iodide and YO-PRO-1 to assess if oxidative stress was associated with necrotic or apoptotic cell death, respectively (Fig. 4). Propidium iodide is non-permeable to the plasma membrane and only cells with a compromised plasma membrane will take up dye that binds to the DNA of necrotic cells. Apoptotic cells, on the other hand, with intact plasma membrane possess the ability to take up YO-PRO-1 that is excluded by viable cells, and has been a common probe to detect apoptotic cells using flow cytometry analysis. The kinetic profile of propidium iodide and YO-PRO-1 fluorescence in P19 cells exposed to the non-ionic surfactant Triton X-100 that permeabilize plasma membranes, the proapoptotic bacterial alkaloid staurosporine, and the CBs HU 210 and AEA are shown in Online Resource 2.

In our hands, the synthetic $\mathrm{CB}$ receptor agonists $\mathrm{HU}$ 210 and WIN 55,512-2, produced a relatively low level of oxidative stress as indicated by an increase in $\mathrm{H}_{2}$ DCFDA fluorescence (Fig. 3). 

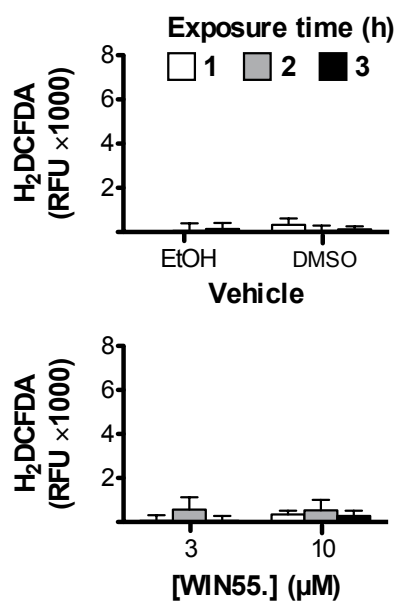
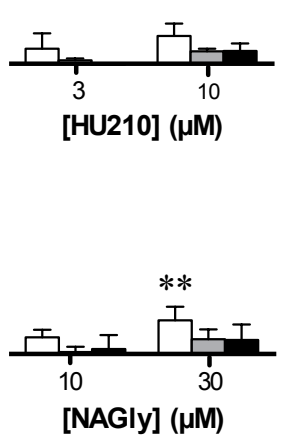

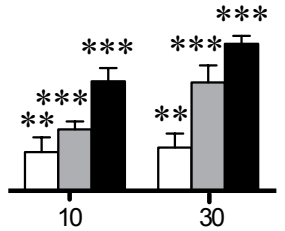

[AEA] ( $\mu \mathrm{M})$

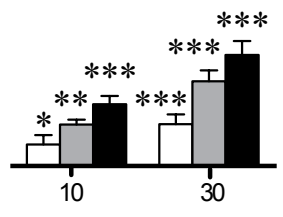

[AA] ( $\mu \mathrm{M})$

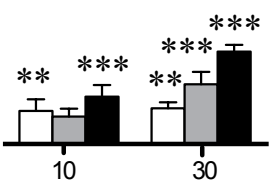

[methAEA] $(\mu \mathrm{M})$

Fig. 3 Oxidative stress, as measured by an increase in the fluorescence of the free radical sensor $\mathrm{H}_{2}$ DCFDA, in P19 EC cells treated with various $\mathrm{CB}$ receptor agonists and related compounds. Data (means \pm SEM of 7-8 independent experiments) are expressed as relative fluorescence units (fluorescence in wells with test compound minus fluorescence in untreated control wells). Statistically significant differences (one-way ANOVA with Dunnett's post-hoc multiple comparison test) are indicated: $* \mathrm{P}<0.05,{ }^{*} * \mathrm{P}<0.01,{ }^{* * *} \mathrm{P}<0.001$, when $\mathrm{H}_{2}$ DCFDA fluorescence values are compared with the fluorescence values in corresponding vehicle $(0.5 \%$ ethanol or $0.5 \% \mathrm{DMSO})$ control wells.

AEA and its metabolically stable analogue meth-AEA produced a major concentration- and time-dependent increase in oxidative stress, and interestingly so did the fatty acid AA that lacks $\mathrm{CB}$ receptor activity but also contains a arachidonoyl moiety as AEA and meth-AEA. However, other fatty acids such as NAGly and EPA produced in this context a relatively small increase in oxidative stress (Fig. 3).

The P19 EC cell death induced by the CBs HU 210,
AEA and meth-AEA involves both necrotic and apoptotic cell death (Fig. 4). However, the relationship between increased levels of ROS and apoptosis and/or necrotic P19 EC cell death is far from clear since the ability of the examined compound to induce fluorescence of $\mathrm{H}_{2}$ DCFDA did not correlate well with cell death. For example, even if $10 \mu \mathrm{M}$ HU 210 induced a modest increase in ROS (Fig. 3), a major cell death was observed after only four hours of incubation (Fig. 4).
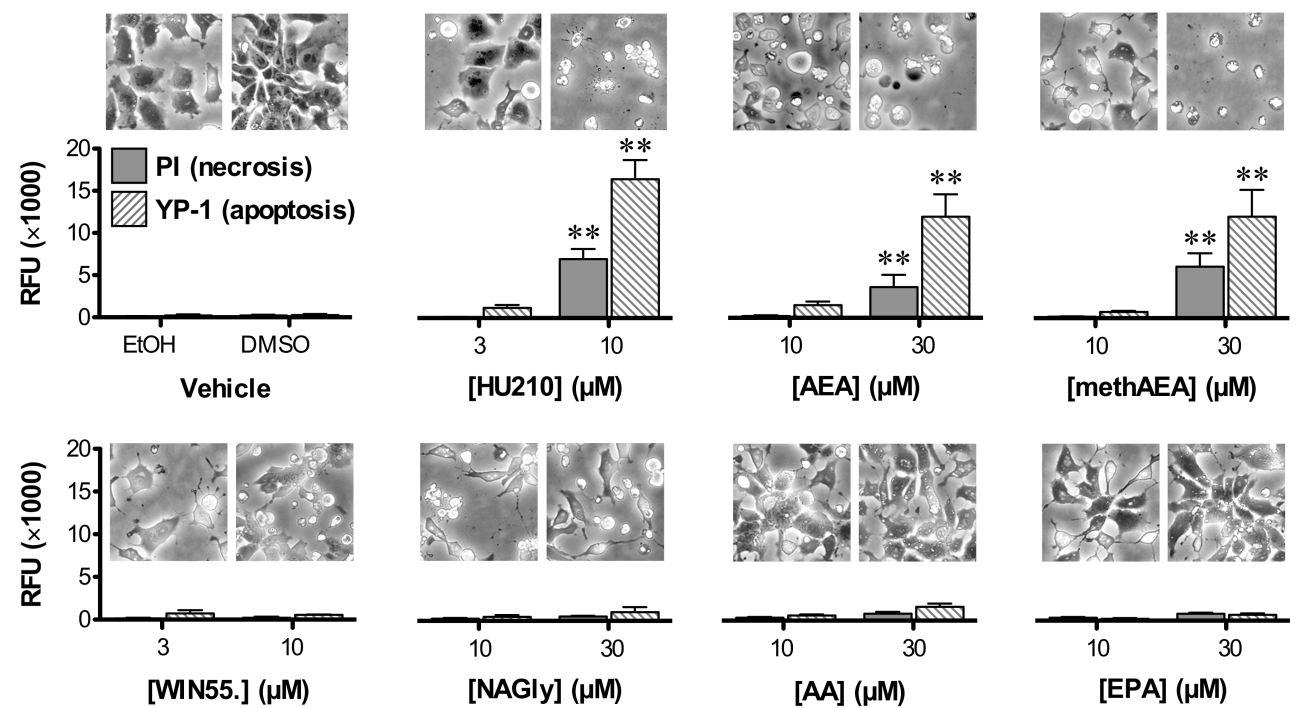

Fig. 4 Necrosis and apoptosis, as measured by an increase in the fluorescence of propidium iodide and YO-PRO-1, respectively, in P19 EC cells after four hours exposure to various CB receptor agonists and related compounds. Data (means \pm SEM of six independent experiments) are expressed as relative fluorescence units (fluorescence in wells with test compound minus fluorescence in untreated control wells). Statistically significant differences (one-way ANOVA with Dunnett's post-hoc multiple comparison test) are indicated: **P < 0.01, when propidium iodide fluorescence values, or YO-PRO-1 fluorescence values are compared with the fluorescence values in corresponding vehicle $(0.5 \%$ ethanol or $0.5 \%$ DMSO) control wells. The upper panels show representative phase-contrast photomicrographs of cell cultures incubated during four hours with indicated compounds and concentrations. 
At that concentration of $\mathrm{HU} 210$, the relative fluorescence units of PI and YO-PRO-1 increased 79fold and 58-fold, respectively, compared to control wells treated with DMSO. The time-course and efficacy to produce this cytotoxicity is almost identical between $3 \mu \mathrm{M}$ HU 210 and $10 \mu \mathrm{M}$ of the well-known inducer of apoptosis, staurosporine (Online Resources 2). Moreover, AEA and methAEA produced a significant increase in the ROS levels at both $10 \mu \mathrm{M}$ and $30 \mu \mathrm{M}$, and as early as after one hour of exposure, but a statistically significant cytotoxicity could only be observed at a concentration of $30 \mu \mathrm{M}$.

Finally, the AA-induced increase of ROS was not accompanied by a significant increase in cell death within four hours of exposure. Within this relatively short incubation time, neither the $\mathrm{CB}$ receptor agonist WIN 55,512-2, nor the fatty acids with structural similarities to AEA, NAGly or EPA, produced any significant increase in oxidative stress or cell death.

The increase in ROS produced by the three compounds with an arachidonoyl moiety AEA, methAEA and AA, was comparable to what was produced by $\mathrm{H}_{2} \mathrm{O}_{2}(100 \mu \mathrm{M}$ or $1 \mathrm{mM})$, as measured by an increase in $\mathrm{H}_{2}$ DCFDA fluorescence (Fig. 5a), and could be significantly attenuated, but not blocked, by co-incubation with the antioxidants $\alpha$-tocopherol (10 $\mu \mathrm{M})$ or $N$-acetylcysteine $(500 \mu \mathrm{M})$. Interestingly, antioxidants such as $\alpha$-tocopherol and $N$ acetylcysteine may have cytoprotective properties unrelated to the direct scavenging of free radicals.

This is suggested by the finding that even if the P19 EC cell death induced by HU 210 was not associated with a massive increase in ROS, the same concentrations of $\alpha$-tocopherol and $N$-acetylcysteine completely blocked the decrease in calcein fluorescence produced by $1 \mu \mathrm{M}$ HU 210 (Fig 5b).

$\alpha$-tocopherol also concentration-dependently attenuated the toxicity produced by $3 \mu \mathrm{M}$ HU 210 , whereas the extracellular antioxidant ascorbic acid was without effect. $\alpha$-tocopherol and $N$-acetylcysteine significantly attenuated the toxicity produced by 10 $\mu \mathrm{M}$ AEA, but all antioxidants were without effect when the cells were challenged with $20 \mu \mathrm{M}$ AEA (Fig. 5b).

We have previously shown that the nitric oxide synthase (NOS) inhibitor L-NAME significantly protected against HU 210- and AEA-induced cytotoxicity in human colorectal carcinoma Caco-2 cells (Gustafsson et al. 2009). Therefore we examined whether L-NAME had the same effect in the P19 EC cells. At a concentration of $100 \mu \mathrm{M}$ (but not at $50 \mu \mathrm{M}$ or $500 \mu \mathrm{M})$, L-NAME protected against the cell death produced by $1 \mu \mathrm{M}$ HU 210 , but had no effect when the cells were challenged with $10 \mu \mathrm{M}$ AEA (Online Resource 3).

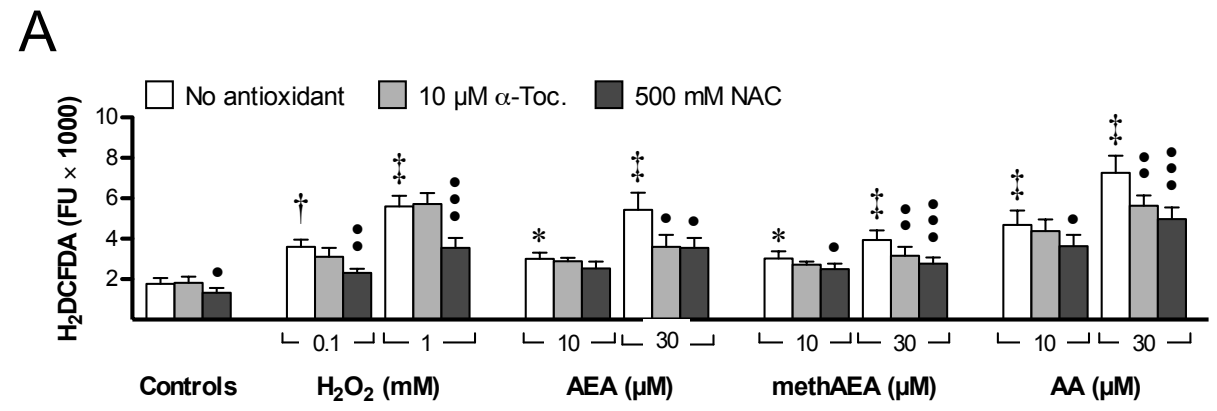

B

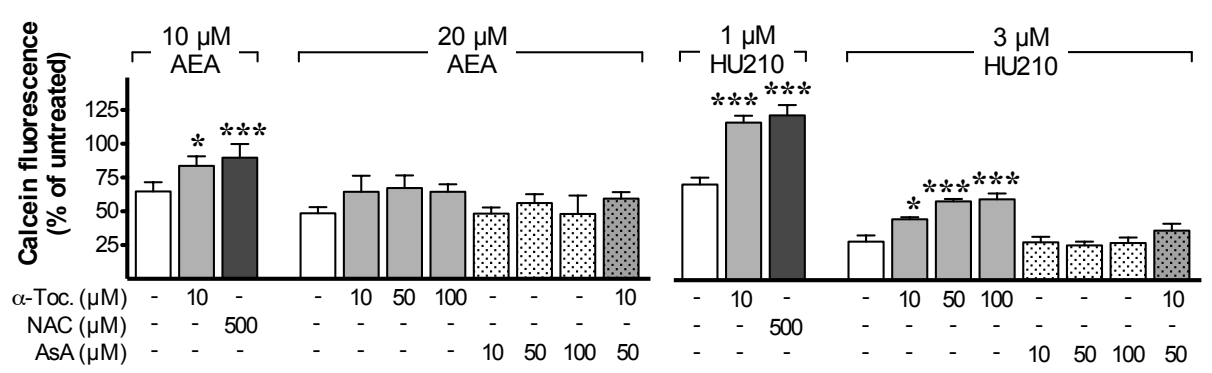

Fig. 5 (a) Effects of the antioxidants $\alpha$-tocopherol ( $\alpha$-Toc.) and $\mathrm{N}$-acetylcysteine (NAC) on the increased levels of reactive oxygen species induced by incubating P19 EC cells with indicated concentrations of hydrogen peroxide (H2O2), AEA, meth-AEA and AA for three hours. (b) Effects of $\alpha$-Toc., NAC and ascorbic acid (AsA) on the cytotoxicity produced by a five hours exposure to AEA and HU210. Data (means \pm SEM of 3-5 independent experiments) are expressed (a) as arbitrary H2DCFDA fluorescence units, or (b) as percentage calcein fluorescence of untreated controls. Statistically significant differences (repeated measures ANOVA in a and one-way ANOVA in b, with Dunnett's post-hoc multiple comparison test) are indicated in (a): $* \mathrm{P}<0.05, \dagger \mathrm{P}<0.01, \ddagger \mathrm{P}<0.001$ for test compounds in the absence of antioxidants vs. untreated controls, and $\mathrm{PP}<0.05,11 \mathrm{P}<0.01,111 \mathrm{P}<0.001$ for antioxidant treatment vs. corresponding concentration test 


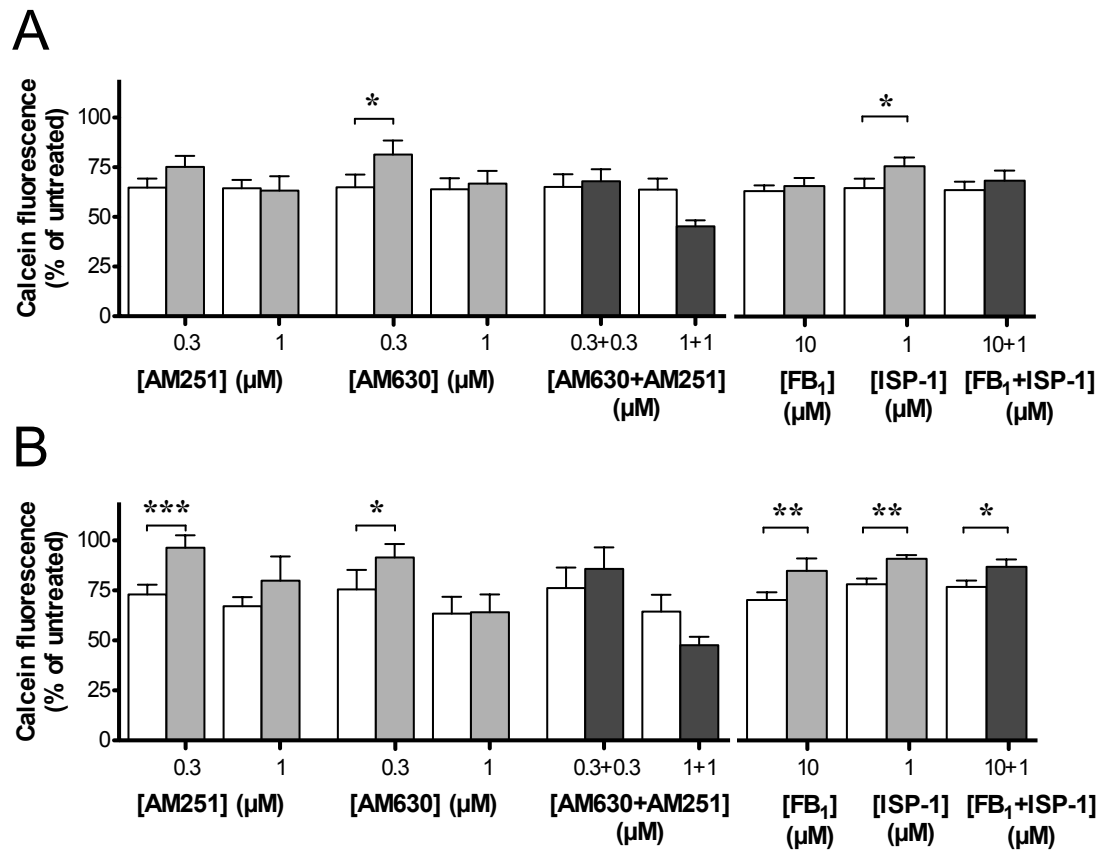

Fig. 6 Effects of the $\mathrm{CB}_{1}$ and the $\mathrm{CB}_{2}$ receptor antagonists $\mathrm{AM} 251$ and $\mathrm{AM} 630$, respectively, the ceramide synthase inhibitor fumonisin $\mathrm{B}_{1}$ $\left(\mathrm{FB}_{1}\right)$, and the serine palmitoyltransferase inhibitor ISP-1 (gray bars) upon the cytotoxicity in P19 EC cells induced by five hours exposure to (a) $10 \mu \mathrm{M}$ of AEA or (b) $1 \mu \mathrm{M}$ of HU 210 (white bars). Data (means \pm SEM of 4-9 independent experiments) are expressed as percentage calcein fluorescence of untreated controls. Statistical treatment of data was undertaken using two-tailed t-test: ${ }^{*} \mathrm{P}<0.05$, $* * \mathrm{P}<0.01$, and $* * * \mathrm{P}<0.001$ (effect of the treatment compared with the corresponding AEA or HU 210 control).

Conclusively, all $\mathrm{CBs}$ with agonistic activity at the CB receptors, except WIN 55,512-2, induce a rapid cell death and fatty acids with an arachidonoyl group may cause a massive production of ROS in cell cultures that only moderately contributes to the CBinduced cell death.

The CB-induced cytotoxicity involves $C B$ receptors and the sphingomyelin-ceramide pathway

A pharmacological approach was employed in order to further elucidate the mechanism(s) behind the AEA- and HU 210-induced cytotoxicity in mouse P19 EC cells. From other studies, it is not completely clear that all of the cellular effects of CBs are mediated by a specific interaction with the membrane-bound $\mathrm{CB}$ receptors. To determine the involvement of $\mathrm{CB}$ receptors in the $\mathrm{CB}$-induced $\mathrm{P} 19$ EC cell death, the cultures were preincubated with the $\mathrm{CB}_{1}$ receptor antagonist $\mathrm{AM} 251$ or the $\mathrm{CB}_{2}$ receptor antagonist AM630. Furthermore, several studies have suggested that the antitumoral effects of $\mathrm{CBs}$ involve sphingomyelin-ceramide and MAPK pathways downstream of CB receptors in cancer cells (Carracedo et al. 2006; Galve-Roperh et al. 2000), and thus the effects of the ceramide synthase inhibitor fumonisin $\mathrm{B}_{1}$, the inhibitor of serine palmitoyltransferase, ISP-1, and the specific inhibitor of mitogen-activated protein kinase kinase (MAPKK1 or MEK1), PD98059 were examined. The cell death produced by a five hour exposure to $10 \mu \mathrm{M}$ AEA could only be attenuated by $0.3 \mu \mathrm{M}$ AM630 and $1 \mu \mathrm{M}$ ISP-1 (Fig. 6a), as measured by changes in the fluorescence of calceinAM. All other tested compounds were without effect against AEA-induced cytotoxicity and the combination of $1 \mu \mathrm{M}$ AM251 $+1 \mu \mathrm{M}$ AM630 even decreased the calcein fluorescence. When applied alone, AM251 or AM630 at a concentration of $3 \mu \mathrm{M}$ were found to decrease the cell viability to about $20 \%$ of untreated P19 cultures (data not shown). In contrast, at a concentration of $0.3 \mu \mathrm{M}$, both AM251 and AM630 significantly attenuated the HU 210induced toxicity (from $73 \pm 5 \%$ to $96 \pm 6 \%$ of untreated control cultures, and from $76 \pm 10 \%$ to $92 \pm$ $7 \%$, respectively; Fig. 6b). However, at a concentration of $1 \mu \mathrm{M}$, or when combined $(0.3 \mu \mathrm{M}$ $\mathrm{AM} 251+0.3 \mu \mathrm{M}$ AM630 or $1 \mu \mathrm{M}$ AM251 $+1 \mu \mathrm{M}$ AM630) the CB receptor antagonists were without significant effects.

Both fumonisin $\mathrm{B}_{1}(10 \mu \mathrm{M})$ and ISP-1 $(1 \mu \mathrm{M})$, reversed the HU 210-induced toxicity, per se or in combination (Fig. 6b), but PD98059 (0.1-25 $\mu \mathrm{M})$ was without effect (data not shown).

The cellular effects of AEA, apart from CB receptor activity, have been associated with agonist activity at 
the transient receptor potential vanilloid 1 (TRPV1) (Zygmunt et al. 1999) and metabolites from a range of

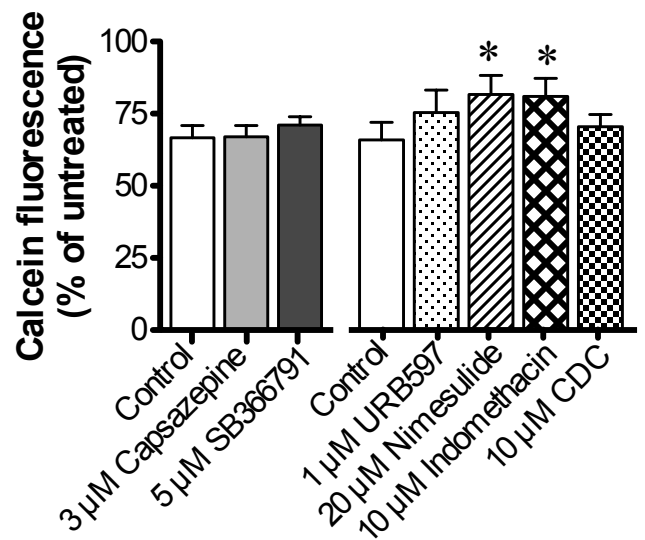

hydrolase (FAAH), cyclooxygenase (COX) and lipooxygenase (LOX), may also contribute to the cytotoxicity of AEA. Furthermore, AEA has been found dose-dependently to induce transcriptional activation of peroxisome proliferator-activated receptor (PPAR) $\gamma$, but also directly to bind to PPAR $\gamma$ and act as an agonist (Bouaboula et al. 2005). The TRPVI antagonists capsazepine and SB366791, and the enzyme inhibitors URB597 (FAAH inhibitor) and CDC (LOX inhibitor) had no effects on the AEAinduced toxicity (Fig. 7). Nimesulide and indomethacin (inhibitors of COX) partly blocked the cytotoxicity produced by $10 \mu \mathrm{M}$ AEA. The PPAR $\gamma$ antagonist GW $9662(1 \mu \mathrm{M}$ or $10 \mu \mathrm{M})$ was also without effect on the cell death produced by $10 \mu \mathrm{M}$ or $30 \mu \mathrm{M}$ of AEA (data not shown).

None of the examined compounds showed any effects in P19 cell cultures incubated with $20 \mu \mathrm{M}$ AA or 20 $\mu \mathrm{M}$ NAGly for five hours (data not shown). Although our results indicate that the $\mathrm{CB}$-induced toxicity in P19 EC cells is mediated at least partly by CB receptors, the effect does not involve PTx-sensitive receptors, since disruption of $\mathrm{G}_{\mathrm{i} / \mathrm{o}}$-coupled receptors by incubation with $100 \mathrm{ng} / \mathrm{ml}$ PTx did not protect against the toxicity produced by HU 210 or AEA (data not shown).

\section{Discussion}

The underlying mechanisms for CB-induced cytotoxicity have not been fully understood and a number of different $\mathrm{CB}$ receptor-dependent and independent cellular pathways have been suggested to be involved. It is obvious that $\mathrm{CBs}$ have dual effects on cell survival and cell death, which is dependent upon the cell type and concentration of $\mathrm{CB}$ used. In this study we used undifferentiated mouse P19 EC cells. EC cells are derived from malignant teratocarcinomas that arise spontaneously in the gonads of mice and humans, and since they express features that are typical of normal embryonic stem intracellular enzymes known to be involved in the endocannabinoid biotransformation, such as fatty acid
Fig. 7 Effects of TRPV1 receptor antagonists capsazepin and SB366791, and inhibitors of the enzymes FAAH, COX and LOX upon the cytotoxicity in P19 EC cells induced by five hours exposure to $10 \mu \mathrm{M}$ of AEA. Data (means \pm SEM of 4-5 independent experiments) are expressed as percentage calcein fluorescence of untreated controls. Statistical treatment of data was undertaken using one-way ANOVA with Dunnett's post-hoc multiple comparison test: $* \mathrm{P}<0.05$ when the effect of the treatment is compared with the corresponding AEA control.
(ES) cells derived from the inner cell mass (ICM) of the early embryo, they have the ability to change phenotype from malignant into non-malignant cells of all germ layers of the organism via the process of cellular differentiation. The P19 EC cells, isolated from teratocarcinoma in $\mathrm{C} 3 \mathrm{H} / \mathrm{He}$ mice, are pluripotent and are particularly useful for studying the effects of $\mathrm{CBs}$ on cell fate, due to the native expression of $\mathrm{CB}$ receptors that are significantly increased upon retinoic acid (RA)-induced neuronal differentiation (Svensson et al. 2006).

In this study, we found that synthetic and endogenous $\mathrm{CBs}$, as well as polyunsaturated fatty acids were all able to promote P19 EC cell death in a concentrationand time-dependent manner, but the cytotoxicity was detected only at relatively high concentrations. Our initial working hypothesis was that the CBs may have antiproliferative effects on the P19 EC cells, and we therefore incubated the cells with the CBs for four days followed by assessments of cell viability. However, by using several different (although partly overlapping) methods to assess cell fate we found that the cytocidal effects of the $\mathrm{CBs}$ prevailed the cytostatic effects. This is advocated by the rapid (within hours) onset of a decrease in calcein fluorescence, and increases in PI and YO-PRO-1 fluorescence by e.g. HU 210, AEA and meth-AEA, and the cell death was also confirmed by microscopy. Even if we suggest that the effects of $\mathrm{CBs}$ are cytocidal rather than antiproliferative, it should be mentioned that both cytocidal and cytostatic effects may contribute to the observed cytotoxicity, but at short incubation times and at higher drug concentrations, the cytocidal effects are easier to observe.

HU 210 potently reduced P19 EC cell viability with an $\mathrm{IC}_{50}$ value around $1 \mu \mathrm{M}$. HU 210 is an analogue of the tricyclic benzopyran $\Delta^{9}$-THC and one of the most potent $\mathrm{CB}_{1}$ and $\mathrm{CB}_{2}$ receptor agonists discovered so far (with reported $K_{\mathrm{i}}$ values of $0.06-1.6 \mathrm{nM}$ at the $\mathrm{CB}_{1}$ 
receptor and $0.52 \mathrm{nM}$ at the $\mathrm{CB}_{2}$ receptor (Burkey et al. 1997; Devane et al. 1992a; Pertwee 1997)). The cytotoxic potency of HU 210 may be of interest since this compound is an important ingredient in "Spice" products, herbal mixtures with added synthetic CBs that are smoked to obtain cannabis-like effects (for a review, see Vardakou et al. 2010). Although it is difficult to make any assumptions about the relevance of our results to the situation in vivo, especially since the cytotoxic effects were found at relatively high concentrations, but prolonged and/or excessive recreational use of HU 210 may be cytotoxic to cells undergoing rapid mitotic division such as immune cells and cells in the developing embryo. Intriguingly, the non-psychotropic enantiomer of HU 210, HU 211 , was as potent as HU 210 in reducing P19 EC cell viability. HU 211 is not a $\mathrm{CB}$ receptor agonist, but instead has antagonistic effects at the NMDA receptor in the CNS. Thus, this argue against the involvement of $\mathrm{CB}$ receptors in the cytotoxic mechanism of $\mathrm{HU}$ 210.

The results obtained when incubating the P19 cells with AEA, meth-AEA, and WIN 55,212-2 are comparable to what has been found in rat C6 glioma cells under identical experimental conditions (Jacobsson et al. 2001). All three compounds have reported agonist activity at the $\mathrm{CB}$ receptors. WIN $55,212-2$ is an aminoalkylindoles with higher affinity for the $\mathrm{CB} 2$ receptor compared to $\mathrm{CB} 1$ receptors $(\mathrm{Ki}$ values are 3.3 and $62.3 \mathrm{nM}$, respectively; Felder et al. 1995), but has also been reported to produce pharmacological effects unrelated to $\mathrm{CB}$ receptor activation (Godlewski et al. 2003; Steffens and Feuerstein 2004). AEA is a partial agonist at the CB receptors (Ki values are 89 and $371 \mathrm{nM}$ at $\mathrm{CB} 1$ and CB2 receptors, respectively), and meth-AEA is a metabolically stable analogue of AEA with approximately 4-fold higher binding affinity for CB1 than AEA (Khanolkar et al. 1996). We have previously performed a similar screening of CBinduced cytotoxicity in human colorectal Caco-2 cells (Gustafsson et al. 2009), where we found that the endogenous structure analogue of AEA, NAGly, and the related polyunsaturated fatty acids AA and EPA (all lacking affinity at the $\mathrm{CB}$ receptors) showed comparable potencies when measuring [3H]thymidine incorporation (although AEA was slightly more potent with an IC50 value of $\sim 23 \mu \mathrm{M}$ compared to $\sim 30 \mu \mathrm{M}$ for AA and EPA). It is even more obvious from the results in the present study that the cytotoxic potencies of AA and EPA are similar to those produced by the $\mathrm{CBs}$ with an arachidonoyl moiety, AEA and meth-AEA (IC50 values for all are between 4.4-7.9 $\mu \mathrm{M})$.

Many of the compounds examined showed a biphasic concentration-response curve, e.g. HU 210 and AEA produced increased calcein fluorescence in the nanomolar range, whereas micromolar concentrations produced a "threshold"-like profile with little or no toxicity at $1 \mu \mathrm{M}$ and maximal toxicity in the range of 3-30 $\mu \mathrm{M}$. This prompted further investigation into bimodal effects on P19 cell viability since it has been shown that $\mathrm{CBs}$ have mitogenic effects on prostate LNCaP cells at submicromolar concentrations (Sanchez et al. 2003) and endocannabinoids have been shown to promote cell proliferation and neurosphere generation in a CB1 dependent manner (Aguado et al. 2005). However, when the apparent stimulatory effects of some of the $\mathrm{CBs}$ on the fluorescence of calcein in P19 cells were re-examined by using the CyQUANT proliferation kit, the $[3 \mathrm{H}]-$ thymidine incorporation assay, and by analysis of cell cycle profile using PI-directed FACScan, it could be concluded that the increased fluorescence in the submicromolar range is not due to increased cellular proliferation. As the calcein signal depends on the cleavage of calcein-AM by intracellular esterases, it cannot be precluded that an increased calcein signal may merely reflect facilitated cleavage of the profluorophore at these low concentrations.

There are many technical difficulties associated with in vitro studies of cellular effects of $\mathrm{CB}$ receptor ligands. A major complication is the high lipophilicity and low water solubility of all $\mathrm{CB}$ molecules, of which many bind avidly to plastics. The use of solubilizing compounds such as DMSO and EtOH may affect the free concentration of CBs in solution and may also have cellular effects per se. For example, DMSO is used to induce P19 EC cells to differentiate into cardiac myocytes (Skerjanc 1999). The induction is performed by incubating cells in suspension with up to $1 \%$ DMSO for at least four days. It is unlikely that the P19 cells in our studies have differentiated during the experiments, since the concentration of DMSO never exceeded $0.5 \%$, and the cells were cultured as adherent cells on tissue culture treated plastics. We have previously shown that the presence of foetal bovine serum in the culture medium affects the cellular sensitivity to $\mathrm{CBs}$ (Jacobsson et al. 2000), and in the present work we found that CB-induced cytotoxicity is also dependent on the cell density, with reduced cytotoxicity at higher cell plating density.

CBs are known to induce apoptosis (Maccarrone et al. 2000; McKallip et al. 2002), and production of reactive oxygen species has been considered one of the major triggers of apoptosis in cells of various origins. The role of oxidative stress in CB-mediated cytotoxicity is far from clear, since e.g. AEAmediated cytotoxicity is associated with increased oxidative stress (Giuliano et al. 2006) but many CBs seem to have antioxidant properties. We found that AEA, meth-AEA and AA produced a significant increase in oxidative stress as measured by increase in the fluorescence of H2DCFDA that was greater than what was produced by other CBs, including HU 210 
and fatty acids. Unexpectedly, the ability of these compounds with an arachidonoyl moiety to produce oxidative stress was comparable to the effect of the well-known oxidizer $\mathrm{H} 2 \mathrm{O} 2$, and the levels of H2DCFDA fluorescence were significantly inhibited by the antioxidants $\alpha$-tocopherol and $\mathrm{N}$-acetylcysteine which may partly explain the mechanism behind the cytoprotective properties of the antioxidant agents against CB-induced cell death (De Lago et al. 2006; Gustafsson et al. 2009; Jacobsson et al. 2001). However, the picture seems to be more complicated since the oxidative properties of the examined compounds do not correlate with the cytotoxicity as measured by increase in PI and YO-PRO-1 fluorescence. Whereas AA and EPA produced a statistically significant increase in oxidative stress without appreciable cytotoxicity, four hours exposure to $10 \mu \mathrm{M}$ HU 210 produced cytotoxicity concomitant with low level of oxidative stress.

Nevertheless, antioxidants were the most efficacious compound examined in protecting against the CBinduced cytotoxicity. Low concentrations $(0.3 \mu \mathrm{M})$ of the $\mathrm{CB} 1$ receptor antagonist AM251 and the CB2 receptor antagonist could reduce the toxicity produced by HU 210. This result is in contrast to what we previously found in human colorectal Caco-2 cells, where neither AM251, AM630 nor pertussis toxin reduced the HU 210-induced toxicity (Gustafsson et al. 2009). Also in the present study, pertussis toxin was unable to affect the toxicity produced by CBs and fatty acids.

An alternative signalling pathway activated by the $\mathrm{CB}$ receptors is the ceramide-pathway (Velasco et al. 2005). Studies have been undertaken in other cell lines where this pathway has been interrupted which has resulted in a reduction in cell toxicity (Carracedo et al. 2006; Ramer et al. 2003). Both the specific ceramide synthase inhibitor fumonisin B1 (Wattenberg et al. 1996), and myriocin (ISP-1) that inhibits serine palmitoyltransferase which is needed for de novo synthesis of ceramide (Miyake et al. 1995), per se and in combination attenuated HU 210induced cytotoxicity. PD98059, an inhibitor of the extracellular signal-regulated kinase (ERK) cascade, was on the other hand without effect. This suggests that the HU 210-induced cytotoxicity in P19 EC cells is involving $\mathrm{CB}$ receptor activation and the the sphingomyelin-ceramide pathway.

AEA have been proposed to produce biological effects by 1) interacting with $\mathrm{CB}$ receptors, 2) interacting with vanilloid TRPV1 receptors, 3) interacting with intracellular PPAR signaling, and 4) being a substrate for various intracellular fatty acid metabolizing enzymes such as FAAH, COX and LOX and thereby elevate intracellular concentrations of e.g.
AA, prostaglandin ethanolamide (prostamides), and HETE ethanolamide, respectively. Moreover, as being a polyunsaturated fatty acid, elevated levels of AEA may change the cellular reduction/oxidation status and contribute to oxidative stress. All abovementioned mechanisms have been addressed in this study, and particularly the pro-oxidative hypothesis has been examined by comparing the toxic effects of AEA with the PUFAs AA and EPA and by demonstrating the cytoprotective effects of antioxidants. Our results suggest that a contributing factor to the cytotoxicity produced by AEA is its fatty acid structure, since the IC50 values are similar to those of $\mathrm{AA}, \mathrm{EPA}$ and the non- $\mathrm{CB}_{1} /$ non- $\mathrm{CB}_{2}$ receptor activating structure analogue of AEA, NAGly. The reduced cytotoxicity of AEA in the presence of COXinhibitors and antioxidants also support a non-CB receptor-mediated mechanism.

On the other hand, some of the effects of AEA must be a consequence of agonism at the $\mathrm{CB}$ receptors, since AEA and meth-AEA, but not AA, EPA nor NAGly produced any significant apopotosis/necrosis within four hours of exposure, even though AA increased reactive oxygen species to a similar level as the CBs. The involvement of $\mathrm{CB}$ receptors is further supported by the small although statistically significant reduction of AEA-induced toxicity (but not AA- or NAGly-induced toxicity) when coincubating the cells with AM630 and $\mathrm{FB}_{1}$.

In conclusion, $\mathrm{CBs}$ are able to promote $\mathrm{P} 19 \mathrm{EC}$ cell death, but at relatively high concentrations and through apparently unspecific mechanisms. Whether the concentrations are "pharmacologically relevant" can be debated, but the potencies found in the P19 EC cells are in the same concentration range as found in several other types of cancer cells (De Petrocellis et al. 1998; Flygare et al. 2005; Gustafsson et al. 2009; Jacobsson et al. 2001; Widmer et al. 2008), and by far exceed the reported affinities of these compounds at the $\mathrm{CB}$ receptors. Hence, the therapeutic potential of $\mathrm{CBs}$, and in particular endogenous CBs, as anticancer drugs may be hampered due to the need of relatively high concentrations that undoubted will raise safety concerns if used in humans. Furthermore, since the P19 EC cells are pluripotent and can undergo irreversible differentiation into all three germ layers and as such serve as a model of developmental toxicity, the results imply that $\mathrm{CBs}$, used recreationally or therapeutically, may interfere with the proliferation and differentiation of stem and progenitor cells during development. This is currently addressed in a study where we investigate the effects of above-mentioned compounds on neuronal development and cytotoxicity in differentiated neurons derived from P19 EC cells 


\section{References}

Aguado T, Monory K, Palazuelos J, Stella N, Cravatt B, Lutz B, Marsicano G, Kokaia Z, Guzman M, Galve-Roperh I (2005) The endocannabinoid system drives neural progenitor proliferation. Faseb J 19:1704-1706

Bouaboula M, Hilairet S, Marchand J, Fajas L, Le Fur G, Casellas P (2005) Anandamide induced PPARgamma transcriptional activation and 3T3-L1 preadipocyte differentiation. Eur J Pharmacol 517:174-181

Burkey TH, Quock RM, Consroe P, Ehlert FJ, Hosohata Y, Roeske WR, Yamamura HI (1997) Relative efficacies of cannabinoid $\mathrm{CB} 1$ receptor agonists in the mouse brain. Eur J Pharmacol 336:295-298

Carracedo A, Gironella M, Lorente M, Garcia S, Guzman M, Velasco G, Iovanna JL (2006) Cannabinoids induce apoptosis of pancreatic tumor cells via endoplasmic reticulum stressrelated genes. Cancer Res 66:6748-6755

De Lago E, Gustafsson SB, Fernandez-Ruiz J, Nilsson J, Jacobsson SO, Fowler CJ (2006) Acyl-based anandamide uptake inhibitors cause rapid toxicity to $\mathrm{C} 6$ glioma cells at pharmacologically relevant concentrations. J Neurochem 99:677-688

De Petrocellis L, Melck D, Palmisano A, Bisogno T, Laezza C, Bifulco M, Di Marzo V (1998) The endogenous cannabinoid anandamide inhibits human breast cancer cell proliferation. Proc Natl Acad Sci U S A 95:8375-8380

Devane WA, Breuer A, Sheskin T, Jarbe TU, Eisen MS, Mechoulam R (1992a) A novel probe for the cannabinoid receptor. J Med Chem 35:2065-2069

Devane WA, Hanus L, Breuer A, Pertwee RG, Stevenson LA, Griffin G, Gibson D, Mandelbaum A, Etinger A, Mechoulam $\mathrm{R}$ (1992b) Isolation and structure of a brain constituent that binds to the cannabinoid receptor. Science 258:1946-1949

Feigenbaum JJ, Bergmann F, Richmond SA, Mechoulam R, Nadler V, Kloog Y, Sokolovsky M (1989) Nonpsychotropic cannabinoid acts as a functional N-methyl-D-aspartate receptor blocker. Proc Natl Acad Sci U S A 86:9584-9587

Felder CC, Joyce KE, Briley EM, Mansouri J, Mackie K, Blond O, Lai Y, Ma AL, Mitchell RL (1995) Comparison of the pharmacology and signal transduction of the human cannabinoid CB1 and CB2 receptors. Mol Pharmacol 48:443450

Flygare J, Gustafsson K, Kimby E, Christensson B, Sander B (2005) Cannabinoid receptor ligands mediate growth inhibition and cell death in mantle cell lymphoma. FEBS Lett 579:6885-6889

Flygare J, Sander B (2008) The endocannabinoid system in cancerpotential therapeutic target? Semin Cancer Biol 18:176-189

Fride E (2008) Multiple roles for the endocannabinoid system during the earliest stages of life: pre- and postnatal development. J Neuroendocrinol 20 Suppl 1:75-81

Galve-Roperh I, Sanchez C, Cortes ML, del Pulgar TG, Izquierdo M, Guzman M (2000) Anti-tumoral action of cannabinoids: involvement of sustained ceramide accumulation and extracellular signal-regulated kinase activation. Nat Med 6:313-319

Giuliano M, Calvaruso G, Pellerito O, Portanova P, Carlisi D, Vento R, Tesoriere G (2006) Anandamide-induced apoptosis in Chang liver cells involves ceramide and JNK/AP-1 pathway. Int J Mol Med 17:811-819

Godlewski G, Gothert M, Malinowska B (2003) Cannabinoid receptor-independent inhibition by cannabinoid agonists of the peripheral 5-HT3 receptor-mediated von Bezold-Jarisch reflex. Br J Pharmacol 138:767-774

Gustafsson SB, Lindgren T, Jonsson M, Jacobsson SO (2009) Cannabinoid receptor-independent cytotoxic effects of cannabinoids in human colorectal carcinoma cells: synergism with 5-fluorouracil. Cancer Chemother Pharmacol 63:691-701

Guzman M (2003) Cannabinoids: potential anticancer agents. Nat Rev Cancer 3:745-755

Hart S, Fischer OM, Ullrich A (2004) Cannabinoids induce cancer cell proliferation via tumor necrosis factor alpha-converting enzyme (TACE/ADAM17)-mediated transactivation of the epidermal growth factor receptor. Cancer Res 64:1943-1950

Jacobsson SO, Rongard E, Stridh M, Tiger G, Fowler CJ (2000) Serum-dependent effects of tamoxifen and cannabinoids upon C6 glioma cell viability. Biochem Pharmacol 60:1807-1813

Jacobsson SO, Wallin T, Fowler CJ (2001) Inhibition of rat C6 glioma cell proliferation by endogenous and synthetic cannabinoids. Relative involvement of cannabinoid and vanilloid receptors. J Pharmacol Exp Ther 299:951-959

Jiang S, Fu Y, Williams J, Wood J, Pandarinathan L, Avraham S, Makriyannis A, Avraham S, Avraham HK (2007) Expression and function of cannabinoid receptors CB1 and CB2 and their cognate cannabinoid ligands in murine embryonic stem cells. PLoS ONE 2:e641

Jiang W, Zhang Y, Xiao L, Van Cleemput J, Ji SP, Bai G, Zhang X (2005) Cannabinoids promote embryonic and adult hippocampus neurogenesis and produce anxiolytic- and antidepressant-like effects. J Clin Invest 115:3104-3116

Khanolkar AD, Abadji V, Lin S, Hill WA, Taha G, Abouzid K, Meng Z, Fan P, Makriyannis A (1996) Head group analogs of arachidonylethanolamide, the endogenous cannabinoid ligand. J Med Chem 39:4515-4519

Lennon SV, Martin SJ, Cotter TG (1991) Dose-dependent induction of apoptosis in human tumor cell lines by widely diverging stimuli. Cell Prolif 24:203-14

Maccarrone M, Lorenzon T, Bari M, Melino G, Finazzi-Agro A (2000) Anandamide induces apoptosis in human cells via vanilloid receptors. Evidence for a protective role of cannabinoid receptors. J Biol Chem 275:31938-31945

Matsuda LA, Lolait SJ, Brownstein MJ, Young AC, Bonner TI (1990) Structure of a cannabinoid receptor and functional expression of the cloned cDNA. Nature 346:561-564

McKallip RJ, Lombard C, Martin BR, Nagarkatti M, Nagarkatti PS (2002) Delta(9)-tetrahydrocannabinol-induced apoptosis in the thymus and spleen as a mechanism of immunosuppression in vitro and in vivo. J Pharmacol Exp Ther 302:451-465

Mechoulam R, Ben-Shabat S, Hanus L, Ligumsky M, Kaminski NE, Schatz AR, Gopher A, Almog S, Martin BR, Compton $\mathrm{DR}$, et al. (1995) Identification of an endogenous 2monoglyceride, present in canine gut, that binds to cannabinoid receptors. Biochem Pharmacol 50:83-90

Miyake Y, Kozutsumi Y, Nakamura S, Fujita T, Kawasaki T (1995) Serine palmitoyltransferase is the primary target of a sphingosine-like immunosuppressant, ISP-1/myriocin. Biochem Biophys Res Commun 211:396-403

Molina-Holgado F, Rubio-Araiz A, Garcia-Ovejero D, Williams RJ, Moore JD, Arevalo-Martin A, Gomez-Torres O, MolinaHolgado E (2007) CB2 cannabinoid receptors promote mouse neural stem cell proliferation. Eur J Neurosci 25:629-634

Munro S, Thomas KL, Abu-Shaar M (1993) Molecular characterization of a peripheral receptor for cannabinoids. Nature 365:61-65

Pacher P, Batkai S, Kunos G (2006) The endocannabinoid system as an emerging target of pharmacotherapy. Pharmacol Rev 58:389-462

Pertwee RG (1997) Pharmacology of cannabinoid CB1 and CB2 receptors. Pharmacol Ther 74:129-180

Plantin-Carrenard E, Bringuier A, Derappe C, Pichon J, Guillot R, Bernard M, Foglietti MJ, Feldmann G, Aubery M, BrautBoucher F (2003) A fluorescence microplate assay using yopro-1 to measure apoptosis: application to HL60 cells subjected to oxidative stress. Cell Biol Toxicol 19:121-133

Rajesh M, Mukhopadhyay P, Hasko G, Liaudet L, Mackie K, Pacher P (2010) Cannabinoid-1 receptor activation induces reactive oxygen species-dependent and -independent mitogenactivated protein kinase activation and cell death in human coronary artery endothelial cells. Br J Pharmacol 160:688-700

Ramer R, Weinzierl U, Schwind B, Brune K, Hinz B (2003) Ceramide is involved in $\mathrm{r}(+)$-methanandamide-induced cyclooxygenase-2 expression in human neuroglioma cells. Mol Pharmacol 64:1189-1198

Rubio-Araiz A, Arevalo-Martin A, Gomez-Torres O, NavarroGalve B, Garcia-Ovejero D, Suetterlin P, Sanchez-Heras E, Molina-Holgado E, Molina-Holgado F (2008) The 
endocannabinoid system modulates a transient TNF pathway that induces neural stem cell proliferation. Mol Cell Neurosci 38:374-380

Rueda D, Navarro B, Martinez-Serrano A, Guzman M, GalveRoperh I (2002) The endocannabinoid anandamide inhibits neuronal progenitor cell differentiation through attenuation of the Rap1/B-Raf/ERK pathway. J Biol Chem 277:46645-46650

Sanchez MG, Sanchez AM, Ruiz-Llorente L, Diaz-Laviada (2003) Enhancement of androgen receptor expression induced by (R)-methanandamide in prostate LNCaP cells. FEBS Lett 555:561-566

Skerjanc IS (1999) Cardiac and skeletal muscle development in P19 embryonal carcinoma cells. Trends Cardiovasc Med 9:139143.

Steffens M, Feuerstein TJ (2004) Receptor-independent depression of DA and 5-HT uptake by cannabinoids in rat neocortex-involvement of $\mathrm{Na}(+) / \mathrm{K}(+)$-ATPase. Neurochem Int 44:529538

Sugiura T, Kondo S, Sukagawa A, Nakane S, Shinoda A, Itoh K, Yamashita A, Waku K (1995) 2-Arachidonoylglycerol: a possible endogenous cannabinoid receptor ligand in brain. Biochem Biophys Res Commun 215:89-97

Svensson AC, Johansson M, Persson E, Carchenilla MSC, Jacobsson SOP (2006) Expression of functional CB1 cannabinoid receptors in retinoic acid-differentiated P19 embryonal carcinoma cells. J Neurosci Res 83:1128-1140

Takeda S, Yamaori S, Motoya E, Matsunaga T, Kimura T, Yamamoto I, Watanabe K (2008) Delta(9)-
Tetrahydrocannabinol enhances MCF-7 cell proliferation via cannabinoid receptor-independent signaling. Toxicology 245:141-146

Taylor AH, Ang C, Bell SC, Konje JC (2007) The role of the endocannabinoid system in gametogenesis, implantation and early pregnancy. Hum Reprod Update 13:501-513

Thomas A, Baillie GL, Phillips AM, Razdan RK, Ross RA, Pertwee RG (2007) Cannabidiol displays unexpectedly high potency as an antagonist of $\mathrm{CB} 1$ and $\mathrm{CB} 2$ receptor agonists in vitro. Br J Pharmacol 150:613-623

Vardakou I, Pistos C, Spiliopoulou C (2010) Spice drugs as a new trend: mode of action, identification and legislation. Toxicol Lett 197:157-162

Velasco G, Galve-Roperh I, Sanchez C, Blazquez C, Haro A, Guzman M (2005) Cannabinoids and ceramide: two lipids acting hand-by-hand. Life Sci 77:1723-1731

Wattenberg EV, Badria FA, Shier WT (1996) Activation of mitogen-activated protein kinase by the carcinogenic mycotoxin fumonisin B1. Biochem Biophys Res Commun 227:622-627

Widmer M, Hanemann CO, Zajicek J (2008) High concentrations of cannabinoids activate apoptosis in human U373MG glioma cells. J Neurosci Res 86:3212-3220

Zygmunt PM, Petersson J, Andersson DA, Chuang H, Sorgard M, Di Marzo V, Julius D, Hogestatt ED (1999) Vanilloid receptors on sensory nerves mediate the vasodilator action of anandamide. Nature 400:452-457 


\section{Online Resource}

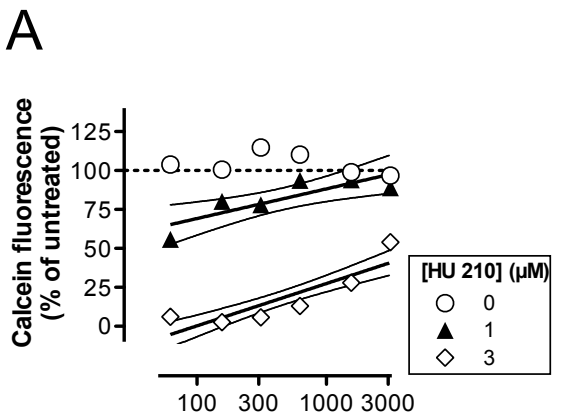

Plating density (cells $/ \mathrm{mm}^{2}$ )
B

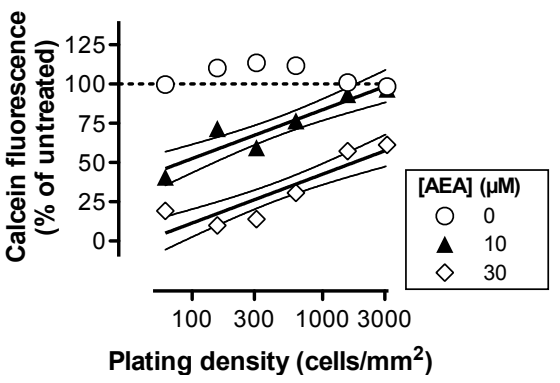

Online Resource Fig. 1 Relationship between the cytotoxicity produced by five hours incubation with (a) HU 210, (b) AEA and the plating density of P19 EC cells. Data are the means of five separate experiments. Linear regression analysis revealed significant deviation from zero ( $\mathrm{P}=0.0034$ and $\mathrm{P}<0.0001$ for $1 \mu \mathrm{M}$ and $10 \mu \mathrm{M}$ HU 210 , respectively, and $\mathrm{P}<0.0001$ for $10 \mu \mathrm{M}$ and $30 \mu \mathrm{M}$ AEA). Dashed lines indicate the $95 \%$ confidence intervals for the regression line.

A

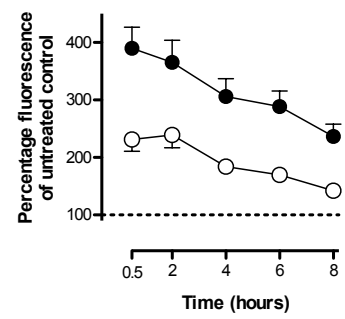

C

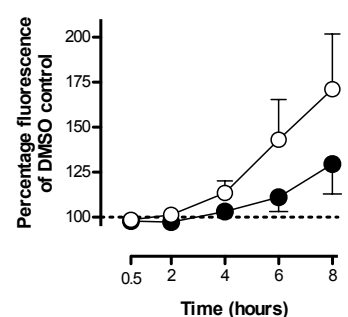

B

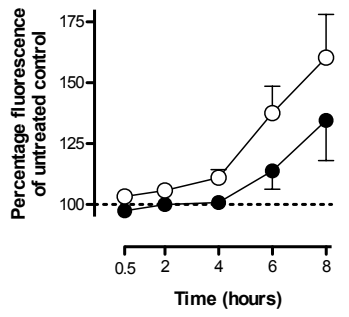

D

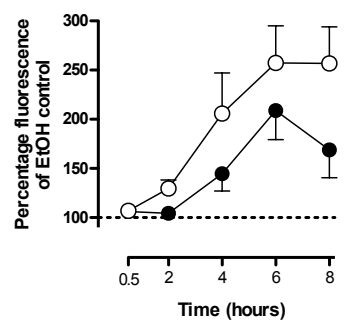

Online Resource Fig. 2 Time-dependent effects of (a) Triton X-100, (b) $10 \mu \mathrm{M}$ staurosporine, (c) $3 \mu \mathrm{M}$ HU 210, and (d) $30 \mu \mathrm{M}$ AEA on YO-PRO-1 (open circles) and propidium iodide (filled circles) fluorescence in P19 EC cells. Data are means \pm SEM of eight separate experiments.

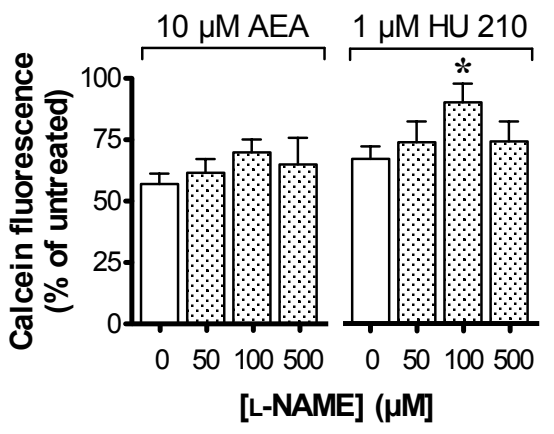

Online Resource Fig. 3 Effects of the the nitric oxide synthase inhibitor L-NAME upon the cytotoxicity in P19 EC cells induced by five hours exposure to indicated concentration of AEA or HU 210. Data (means \pm SEM of four independent experiments) are expressed as percentage calcein fluorescence of untreated controls. Statistical treatment of data was undertaken using one-way ANOVA with Dunnett's post-hoc multiple comparison test: $* \mathrm{P}<0.05$ when the effect of the treatment is compared with the corresponding AEA or HU210 control. 